\title{
Pencitraan BUMN Dalam Media Online
}

\author{
Hana Silvana \\ Harry Kurniawan
}

\author{
Universitas Pendidikan Indonesia \\ Jl. Setiabudhi No.229 Bandung \\ E mail : hanasilva@upi.edu
}

\begin{abstract}
ABSTRAK
Pada perkembangannya media massa lebih mengarah pada media online. Dalam arus penyebaran informasi media online menjadi lebih luas dan cepat. Penelitian ini bertujuan untuk mendeskripsikan citra perusahaan pada PT.PLN (Persero) pada pemberitaan media online. Penelitian ini menganalisis isi konten pemberitaan terkait perusahaan pada isu subsidi listrik tepat sasaran 2016. Pendekatan penelitian menggunakan penelitian kuantitatif. Metode yang digunakan pada penelitian ini adalah analisis isi. Dari kategori dan indikator yang telah ditentukan, ditemukan bahwa banyak digunakan nada pernyataan buruk pada judul berita namun tidak sama halnya dengan isi konten berita yang cenderung mendapatkan penilaian positif. Hal itu dikarenakan narasumber yang dominan dan terdapat dalam konten pemberitaan merupakan pihak-pihak yang terlibat dalam proses pembuatan kebijakan subsidi listrik tepat sasaran. Hasil penelitian ini dapat disimpulkan bahwa perusahaan PT.PLN (Persero) dalam penelitian ini mendapatkan citra yang positif dari pemberitaan di media online detik.com terkait Isu Subsidi Listrik Tepat Sasaran 2016.
\end{abstract}

Kata Kunci: Citra perusahaan, PLN, Subsidi, Kebijakan

\begin{abstract}
In its development, mass media is more directed at online media. In the flow of information dissemination online media becomes wider and faster. This study aims to describe the company's image to PT. PLN (Persero) on online media coverage. This study analyzes the content of news related content about the company on the issue of electricity subsidies on target 2016. The research approach uses quantitative research. The method used in this study is content analysis. From the categories and indicators that have been determined, it was found that many used bad statement tones in the headline but not the same as the content of news content which tended to get a positive rating. This is because the dominant sources included in the news content are those involved in the process of making electricity subsidy policy on target. The results of this study can be concluded that the company PT PLN (Persero) in this study get a positive image from the news on detik.com online media related to the Issue of the Right Target Electricity Subsidy 2016.
\end{abstract}

Keywords: Company image, PLN, Subsidies, Policy 


\section{PENDAHULUAN}

Seiring dengan perkembangan zaman semakin kompleks pula permasalahan yang terdapat dalam suatu perusahaan ,dewasa ini perusahaan membutuhkan faktor lain guna mengukur pencapaian disamping faktor finansial. Tren dewasa ini perusahaan berlomba-lomba mendapatkan pemberitaan yang baik di media, hal tersebut sematamata untuk mendapatkan citra positif, dan citra positif memberikan kesuksesan jangka panjang bagi perusahaan.

Beberapa manfaat mendapatkan citra yang positif bagi perusahaan antara lain daya saing jangka menengah dan panjang yang mantap (mid and long tern sustainable competitive position), menjadi perisai selama masa krisis (an insurance for adverse times), menjadi daya tarik eksekutif handal (attracting the best executives available), meningkatkan efektivitas strategi pemasaran (increasing the effectiveness of marketing instruments), penghematan operasional (cost savings), (Siswanto Sutojo, 2004, hlm. 3). Oleh karena itu sudah seharusnya perusahaan memantau segala pembentukan opini terkait perusahaan demi menjaga citra positif di masyarakat secara kontinuitas, salah satunya ialah dengan cara media monitoring.

Citra positif dibutuhkan oleh semua perusahaan tak terkecuali PT.PLN (Persero), yakni sebagai perusahaan jasa pelayanan dan penyedia di bidang kelistrikan. Pada awalnya kepemilikan perusahaan sempat dikelola oleh Belanda dan Jepang, kemudian pada tahun 1972 PT. PLN (Persero) ditetapkan sebagai perusahaan umum listrik negara sesuai dengan peraturan pemerintah no.17 dan sebagai Pemegang Kuasa Usaha Ketenagalistrikan (PKUK) dengan tugas menyediakan tenaga listrik bagi kepentingan umum. Seiring dengan perubahan kebijakan dari pemerintah, pada tahun 1994 status perusahaan berganti yang semula berbentuk perusahaan umum berubah menjadi perusahaan persero dimana pemerintah memberikan kesempatan pada sektor swasta untuk bergerak dalam bidang kelistrikan.

Citra yang baik bagi PLN menjadi indikator kualitas kinerja dan keberhasilan perusahaan sesuai dengan visi yang diusung yaitu diakui sebagai perusahaan kelas dunia yang tumbuh dan berkembang, unggul dan terpercaya. Awal tahun 2016 PT.PLN (Persero) tengah dijadikan sorotan publik dan gencar diberitakan di berbagai lini media massa terkait dengan isu kebijakan Subsidi Listrik Tepat Sasaran. Isu dijelaskan dalam Nova (2011, hlm.239) ialah peristiwa yang terjadi di luar kendali perusahaan yang berdampak pada tujuan strategis perusahaan yang mungkin memerlukan respons tertentu dari perusahaan. 
Kebijakan tersebut dilakukan guna menghemat anggaran negara dikarenakan adanya ketidaksesuaian data jumlah pelanggan miskin yang dimiliki pemerintah dengan yang dimiliki PT.PLN (Persero). Seperti yang kita tahu bahwa pelanggan yang dikategorikan miskin oleh pemerintah mendapatkan subsidi listrik, khususnya golongan 450 volt amphere (VA) dengan 900 VA. Golongan yang mendapatkan subsidi ini berjumlah sekitar 45,6 juta sedangkan berdasarkan data dari Tim Nasional Percepatan Penanggulanagn Kemiskinan (TNP2K), jumlah masyarakat miskin dan rentan miskin ialah sekitar 24,7 juta orang. Artinya ada sekitar 23,3 juta pelanggan listrik PT.PLN (Persero) rumah tangga yang sebenarnya tidak berhak untuk mendapatkan subsidi.

Kebijakan ini akan menimbulkan pro-kontra terutama di kalangan masyarakat itu sendiri, seperti yang disebutkan oleh Kepala Humas PT.PLN (Persero) APJ Banten Utara Drs.Sismanto berkomentar:

"Kami memahami keberatan yang dirasakan pelanggan karena memang listrik merupakan kebutuhan primer tetapi dengan pemahaman masyarakat yang minim mengenai isu tersebut, masyarakat pasti akan menganggap PLN tidak pro pada rakyat, padahal tujuan sebenarnya dilakukan kebijakan ini ialah untuk rakyat itu sendiri dan masyarakat yang lebih luas. Perlu diketahui juga bukan PLN yang membuat dan memutuskan kebijakan tersebut melainkan Menteri Energi Sumber daya Mineral (ESDM), sesungguhnya PLN tidak memiliki wewenang dan hanya mengikuti instruksi yang diberikan dari atasan (ESDM), sekali lagi saya tegaskan PLN bukan mencabut subsidi melainkan menyesuaikan pada yang lebih berhak mendapatkannya".

Awalnya kebijakan ini akan dilakukan pada awal tahun 1 januari 2016 namun terdapat penundaan akibat adanya kendala dalam pendataan masyarakat yang tergolong miskin dan belum diputuskannya kebijakan ini oleh Presiden Jokowi, hal tersebut tidak membuat praktisi public relations di perusahaan memiliki waktu untuk bersantai dalam mengahadapi isu, karena opini yang terdapat di publik sewaktu-waktu bisa berubah dan dapat menjadi opini yang perusahaan tidak inginkan sama sekali (O’Leary, 2015, hlm. 208).

Listrik adalah kebutuhan pokok yang tidak bisa dipisahkan manusia modern, setiap hari bahkan setiap saat manusia membutuhkan listri. Hal yang wajar apabila Informasi mengenai kebutuhan pokok akan menjadi perhatian lebih dari masyarakat luas dibanding informasi lain. Momentum seperti ini akan dimanfaatkan media dengan kekuatan agenda settingnya mengarahkan publik untuk mengakses informasi dan membahas isu tertentu (Moshrefzadeh, hlm. 4446). Seperti contoh kasus perusahaan airbag Takata, terdapat masalah pada produk yaitu kerusakan inflators airbag. Akibatnya timbul korban tewas dari perusahaan alat penunjang keselamatan 
pada kendaraan ini. Masalah yang dialami Takata mendapat perhatian serius dan gencar diberitakan di media-media dikarenakan terdapat 10 parbrikan mobil yang menggunakan produk Takata dan telah berada di tangan konsumen sehingga mengakibatkan terjadinya recall sebanyak lebih dari 30 juta unit kendaraan. Akhirnya beberapa perusahaan pabrikan mobil satupersatu memutus kontrak dan Takata pun menghadapi krisis terbesar sepanjang sejarah perusahaan tersebut.

Berdasarkan penelitian yang dilakukan oleh Anne Van Der Pijl (2015, hlm. 31) menyebutkan bahwa manusia lebih tertarik dengan judul yang bernada negatif, maka pemberitaan di media yang berhubungan dengan perusahaan perlu mendapatkan perhatian lebih dari PR. Terutama pada saat terdapat isu sensitif yang berpotensi merugikan citra perusahaan karena media massa dengan kemampuan persuasifnya yang dapat membentuk opini khalayak luas, tidak bisa dikontrol oleh perusahaan dalam proses pembuatan pesan itu sendiri (Cutlip, Center \& Broom, 2006, hlm 286).

Efek pemberitaan di media massa yang tidak berimbang dan cenderung menjatuhkankan akan memberikan dampak negatif bagi citra perusahaan di masyarakat karena ciri paling utama dari media massa ialah mereka dibuat untuk menjangkau banyak orang, memiliki aliran satu arah, serta distribusi dan penerimaan konten dalam skala besar (McQuail, 2010, hlm. 63). Pengaruh yang lebih berbahaya dari pemberitaan di media dijelaskan dalam Mcnamara di penelitiannya berjudul Media content analysis: Its uses; benefits and best practice methodology bahwa media massa diyakini menyebabkan kekerasan, seks bebas dan berkontribusi diskriminasi terhadap perempuan. Berita di media terkemuka telah terbukti secara signifikan mempengaruhi harga saham, menyebabkan runtuh perusahaan, penyebab jatuh penjualan produk, mengakibatkan pengunduran diri petinggi perusahaan bahkan menurunkan Presiden (2005, hlm. 1).

Seperti contoh berita yang dikutip dari portal berita online Sindonews.com (sumber catatan kaki) yang berjudul "YLKI Tolak Pencabutan Subsidi Listrik”, berita tersebut berisikan pandangan ada alasan dibalik kebijakan subsidi listrik tepat sasaran. Disebutkan bahwa dilakukannya kebijakan tersebut tidak tepat mengingat kondisi perekonomian yang sedang terpuruk, kebijakan ini hanyalah kedok pemerintah dan PLN saja dalam menerapkan tarif dengan mengikuti mekanisme pasar yang baru dan PLN lupa tugasnya sebagai pelayan masyarakat sehingga apabila tetap dilakukan akan berdampak kepada menurunnya daya beli 
masyarakat. ${ }^{1}$ Perlunya respon cepat dari perusahaan karena berdasarkan hasil penelitian yang dilakukan Houken dan Renkema tentang The Influence of Negative Newspaper Publicity on Corporate Image in the Netherlands bahwa sulit untuk menganggap remeh kerusakan pemberitaan negatif. Terutama rusaknya kepercayaan dirasakan perusahaan sangat besar(1998, hlm.532). Akibatnya di kebijakan mendatang yang akan dilakukan perusahaan bukan tidak mungkin pelanggan akan berpersepsi buruk terlebih dahulu.

Namun yang terjadi berbanding terbalik apabila pemberitaan terkait perusahaan disajikan objektif dan menjelaskan secar rinci bagaimana kebijakan subsidi dilakukan dan untuk apa, sehingga dapat memberikan suatu perubahan yang baik bagi citra perusahaan. Perubahan tersebut disebut output, outputnya adalah meningkatnya pengetahuan dan perubahan perilaku (McQual, 2010, hlm. 123).

Meningkatnya pengetahuan yang dimaksud ialah masyarakat mengetahui apa yang terjadi dan bagaimana secara teknis kebijakan subsidi tepat sasaran dilakukan, adapun perubahan perilaku yang dimaksud ialah masyarakat yang semula kontra dan menganggap PT.PLN tidak pro terhadap rakyat menjadi netral dalam menanggapinya.

Di sinilah peran Public Relations (PR) sebagai lini depan dari perusahaan untuk melakukan manajemen isu yakni mengantisipasi, mengidentifikasi mengevaluasi dan merespon isu isu kebijakan publik yang memengaruhi hubungan organisasi mereka dengan publik mereka (Cutlip, 2009, hlm. 24). Isu apabila dibiarkan akan berakibat krisis pada perusahaan, sehingga bila penyebarluasan informasi tentang krisis yang dialami oleh perusahaan tidak ditangani dengan baik bisa hal tersebut bisa mengancam citra atau reputasi organisasi atau perusahaan. Akan diperlukan waktu yang lama untuk memulihkan kembali citra atau reputasi yang telah dibangun. (Iriantara, 2005, hlm. 177).

Penelitian ini mengkaji pemberitaan media massa terhadap PT.PLN (Persero) menggunakan metode analisis isi. Dari beberapa jenis media massa penulis memilih memfokuskan pada media online karena berbagai alasan kelebihannya dibandingkan dengan media massa konvensional. Kelebihan media online dibandingkan media konvensional ialah dapat memperbarui informasi secara langsung dan cepat serta menyertakan foto, video, dan audio peristiwa (Richard, 2005, hlm. 9). 
Adapun alasan pribadi penulis dalam memilih media online ialah munculnya portal berita online dari berbagai perusahaan media. Kecepatan up to date informasi yang terdapat di media online, serta perkembangan teknologi yang telah mengubah gaya hidup masyarakat modern sehingga setiap individu bisa dengan mudah dalam mencari sumber dan mendapatkan kebutuhan pemenuhan informasi yang dibutuhkan menjadi salah satu pertimbangan yang penulis pilih.

Detik.com ialah portal berita online yang dipilih penulis untuk melakukan penelitian ini, alasan yang dipilih ialah karena portal berita online detik.com digemari dan banyak dikunjungi oleh pembaca sehingga memiliki dailiy visitor/pengunjung harian yang sangat tinggi. Berdasarkan data yang diambil dari situs Statshow jumlah pengunjung harian Detik.com berada di angka 1.506.029 pengunjung. $^{2}$

Kotler dan Fox dalam Sigit dkk (2012, hlm 116) menyebutkan ada berbagai cara di mana organisasi dapat mengumpulkan informasi tentang citra perusahaan. Salah satunya melakukan kontak teratur dengan orang-orang dari berbagai jenis publik yang relevan sehingga dapat memberikan beberapa gambaran yang mereka memiliki tentang organisasi. Tetapi belum tentu memberikan representasi yang handal maka dari itulah dilakukan melalui metode analisis isi dengan cara media monitoring, dengan cara ini akan dievaluasi setiap berita yang ditulis di pemberitaan media sehingga isi pesan dapat terlihat dengan jelas.

Penelitian ini menggunakan unsur elemen citra yang disebutkan oleh Vos (1992, hlm. 109) bahwa citra perusahaan dapat diukur melalui keakraban, karakteristik, posisi, sumber, dan penilaian. Elemen citra yang pertama ialah keakraban yakni pengenalan publik mengenai organisasi, pengenalan yang dimaksud meliputi produk, layanan, kebijakan, dan hal lainnya. Elemen yang kedua karakteristik ialah mengarah pada kesan yang ditunjukkan oleh publik menggunakan kata ganti tertentu yang diingat oleh publik. Elemen yang ketiga posisi adalah bagaimana posisi perusahaan apabila dibandingkan dengan perusahaan lainnya. Elemen yang keempat sumber ialah melihat bagaimana media memilih narasumber untuk dimintai opini terkait organisasi atau perusahaan yang bersangkutan dan didapatkan elemen citra yang terakhir yaitu penilaian. Dari kelima elemen citra di atas, elemen posisi tidak digunakan dalam penelitian ini dikarenakan PT.(PLN) Persero tidak memiliki kompetitor dalam menjalankan usahanya. 
Oleh karena itu, peneliti akan melakukan penelitian melalui metode analisis isi mengenai citra PT.PLN (Persero) terkait isu Subsidi Listrik Tepat Sasaran 2016 di portal berita Detik.com dalam periode waktu selama 8 bulan dimulai dari bulan November 2015 hingga bulan Juni 2016.

\section{METODE}

Jenis penelitian yang digunakan ialah deskriptif. Penelitian ini menggunakan metode analisis isi. Eriyanto (2011, hlm.1) menjelaskan semua metode analisis ini mempunyai tujuan yang sama, yakni memahami isi (content), apa yang terkandung dalam isi dokumen. populasi yang digunakan ialah seluruh pemberitaan mengenai PT.PLN (Persero) terkait isu subsidi listrik tepat sasaran di media online detik.com dalam rentang waktu dari bulan November 2015 hingga bulan Juni 2016. Mengacu kepada Sugiyono sampel adalah sebagian dari jumlah dan karakteristik yang dimiliki oleh populasi (2010, hlm.118). Sampel yang digunakan dalam penelitian ini ialah seluruh berita terkait subsidi listrik tepat sasaran selama periode yang telah ditentukan sebelumnya. Teknik penarikan sampel yang digunakan dalam penelitian ini adalah purposive sampling yaitu peneliti secara sengaja memilih sampel atau periode tertentu atas dasar pertimbangan ilmiah. Pemilihan sampel memang tidak dilakukan secara acak, tetapi berdasar pertimbangan (judgement) yang kuat dari peneliti (Eriyanto 2011, hlm. 147)

\section{HASIL DAN PEMBAHASAN}

Elemen Keakraban, terdapat tiga kategori keakraban dalam penelitian yang akan dijabarkan hasilnya, yaitu kebijakan, kinerja, dan layanan. Berdasarkan hasil koding yang telah peneliti lakukan dari 39 berita, konten pemberitaan PT.PLN (Persero) mengenai kebijakan yang positif sebanyak 18 berita (46,2\%), konten pemberitaan yang negatif sebanyak 12 (30,8\%) berita, dan konten pemberitaan yang netral sebanyak 9 berita (23\%). Dimensi kedua dari elemen keakraban ialah kinerja perusahaan. Kinerja perusahaan di sini dilihat dari bagaimana pemberian informasi mengenai progres kinerja perusahaan dalam melaksanakan kebijakan yang bersangkutan. Berdasarkan hasil kodingan, kinerja perusahaan di pemberitaan media online detik.com mendapatkan nilai positif sebanyak 22 berita dari 39 berita $(56,4 \%)$, sedangkan berita memberi pernyataan negatifsebanyak 6 berita (15,4\%), adapun pemberitaan yang netral sebanyak 11 berita (28,2\%). Dimensi layanan ialah dilihat dari bagaimana pemberitaan di media online detik.com memuat informasi mengenai layanan perusahaan yang diberikan kepada pelanggan 450 VA dan 900 VA data 
menunjukkan pemberitaan mengenai yang diambil oleh media dalam layanan cenderung bersifat netral, data lebih jelasnya ialah dari 39 berita yang diteliti 31 berita memberitakan netral (79,5\%), positif sebanyak 5 berita (12,8\%), dan negatif sebanyak 3 berita $(7,7 \%)$.

Kategori karakteristik dalam penelitian ini terbagi dalam dua dimensi yaitu keuangan dan perencanaan formal (program), berikut adalah penjabaran hasilnya. Hasil temuan peneliti terkait keuangan perusahaan menunjukkan pemberitaan netral mendapatkan hasil terbanyak dari 39 berita yang diteliti, yaitu sebanyak 23 berita (59\%), pemberitaan buruk sebanyak 11 berita (28,2\%), dan pemberitaan keuangan yang mendapat predikat baik hanya sebanyak 5 berita (12,8\%). Kategori perencanaan formal (program) diartikan sebagai program perusahaan yang masih dalam ruang lingkup subsidi listrik tepat sasaran. Berdasarkan kodingan yang peneliti telah lakukan dari 39 artikel berita selama periodesasi yang telah ditentukan, data menunjukkan pemberitaan terkait program yang positif dan pemberitaan yang netral memiliki jumlah yang sama yaitu sebanyak 7 artikel berita (17,9\%), sedangkan pemberitaan netral yang hanya bersifat informatif mendapatkan hasil yang tertinggi yaitu sebanyak 25 berita $(64,1 \%)$.

Kategori sumber mengacu kepada kutipan atau pernyataan di pemberitaan menanggapi atau memberikan informasi seputar subsidi listrik tepat sasaran. Berdasarkan kodingan hasil penelitian yang telah dilakukan oleh peneliti, menemukan bahwa publik yang paling banyak dijadikan narasumber dan terdapat dalam pemberitaan ialah dari Pembuat Kebijakan. Jumlah berita dengan narasumber dari Pembuat Kebijakan ialah sebanyak 24 berita atau sebesar 51,1\%, posisi kedua narasumber ialah dari Direksi dengan 9 jumlah berita atau sebesar 19,1\%. Posisi ketiga narasumber ditempati oleh Pegawai dengan jumlah 6 berita atau sebesar 12,8\%. Posisi keempat diisi oleh Pemerintah dengan jumlah berita 5 atau sebesar 10,6\%. Selanjutnya ialah berasal dari Pemuka Pendapat dengan jumlah 2 berita atau 4,3\% dan Pelanggan dengan jumlah 1 berita atau $2,1 \%$. Untuk narasumber yang berasal dari Lembaga Swadaya Masyarakat dan Lainlain tidak ditemukan dalam pemberitaan. Penilaian dilihat dari hasil nilai akhir atau kecenderungan dari suatu pemberitaan. Berdasarkan hasil kodingan pemberitaan rentang November 2015 - Juni 2016. Penilaian dari seluruh pemberitaan perusahaan terkait Isu Subsidi Listrik Tepat Sasaran 2016 ialah cenderung positif. Artikel berita yang memilki penilaian positif ialah sebanyak 18 berita atau sebesar 46,2\%. Sedangkan artikel berita yang memiliki penilaian negatif ialah sebanyak 
13 berita atau sebesar 33,3\%. Adapun sisanya sebanyak 8 artikel berita atau sebesar 20,5\% memiliki kecenderungan penilaian netral.

Secara keseluruhan pemberitaan mendapatkan nilai kecenderungan yang baik dari pemaparan isi berita namun tidak dengan judul yang dimana banyak digunakan kata yang merujuk pada tonalitas yang buruk, hal itu digunakan guna menarik peminat pembaca seperti yang disebutkan oleh Anne Van Der Pijl (2015, hlm. 31) yang menyebutkan bahwa manusia lebih tertarik dengan judul yang bernada negatif. Dengan digunakannya penggunaan kata negatif akan lebih menarik pembaca untuk membaca artikel berita tesebut.

\section{SIMPULAN}

Penelitian yang berjudul "Citra PT.PLN (Persero) di Media Online terkait isu Subsidi Listrik Tepat Sasaran 2016” ini menggunakan metode analisis isi dengan menggunakan elemen citra menurut Vos (1992). Setelah dilakukan koding dari setiap elemen dan kategori yang telah dibuat, terlihat kecenderungan nilai akhir dari citra perusahaan. Hasil akhir dari penelitian ini ialah PT.PLN (Persero mendapatkan citra yang positif pada pemberitaan di portal berita Detik.com terkait isu Subsidi Listrik Tepat Sasaran 2016. Artikel berita yang memilki penilaian positif ialah sebanyak 18 berita atau sebesar
46,2\%. Sedangkan artikel berita yang memiliki penilaian negatif ialah sebanyak 13 berita atau sebesar 33,3\%. Adapun sisanya sebanyak 8 artikel berita atau sebesar 20,5\% memiliki kecenderungan penilaian netral. PT.PLN (Persero) . Saran dari penulis ialah perusahaan diharapkan menjalin lebih luas hubungan dengan berbagai media massa lainnya guna mencapai publikasi yang lebih maksimal dalam pemberitaan pada kebijakan yang akan mendatang.

\section{DAFTAR PUSTAKA}

\section{Buku}

Ardianto, Alvinaro. (2011) Handbook Of Public Relations. Pengantar Komprehensif. Bandung : Remaja Rosdakarya Bandung.

Budyatna, Muhammad. (2012). Jurnalistik Teori dan Praktik. Bandung : PT Remaja Rosdakarya.

Cutlipp, Scott dkk. (2009). Effective Public Relations Edisi Kesembilan. Jakarta : Kencana Prenada Media Group.

Eriyanto. (2011). Analisis Isi : Pengantar Metodologi Untuk Penelitian Ilmu Komunikasi dan Ilmu-Ilmu Sosial Lainnya. Jakarta : Kencana Prenada Media Group.

Elvinaro, dkk. (2007). Komunikasi Massa Suatu Pengantar Edisi Revisi. Bandung: Simbiosa Rekatama Media.

Hikmat, Mahi M. (2011). Metode Penelitian Dalam Perspektif Ilmu Komunikasi dan Sastra. Yogyakarta : Graha Ilmu. 
Iriantara, Yosal. (2005). Media Relations : Konsep, Pendekatan, dan Praktik. Bandung: Simbiosa Rekatama Media.

Kriyantono, Rachmat. (2006). Teknik Praktik Riset Komunikasi. Jakarta : Kencana Prenada Media Group.

Kriyantono, Rachmat. (2014). Teori Public Relations Perspektif Barat \& Lokal Aplikasi Penelitian dan Paktik. Jakarta: Kencana Prenamedia Group.

McQuail, Dennis. (2011) Teori Komunikasi Massa: McQuail Mass Communication Theory, 6th ed. Jakarta : Penerbit Salemba Humanika.

Neuendorff, Kimberly A. (2002). The Content Analysis Guidebook. Thousand Oaks: Sage Publications.

Nova, Firsan. (2011). Crisis Public Relations: Strategi PR Menghadapi Krisis, Mengelola Isu, Membangun Citra, dan Reputasi Perusahaan. Jakarta: Rajawali Pers.

Rivers, William dkk. (2003). Media Massa \& Masyarakat Modern Edisi Kedua. Jakarta : Kencana Prenada Media Group.

Riyanto. (2008). Analisis Pengaruh Karakteristik Perusahaan Dan Strategi Internasional Terhadap Kinerja Ekspor Perussahaan Dengan Lingkungan Sebagai Moderating Variabel (Studi pada UKM eksportir di Semarang). (Thesis). Fakultas Pasca Sarjana Universitas Diponegoro Semarang.

Soemirat, Ardianto. (2008). Dasar-Dasar Public Relations. Bandung: PT. Remaja Karya Rosada.

Sugiyono. (2010). Statistik Untuk Penelitian. Bandung: Alfabeta.

Sugiyono. (2012). Metode Penelitian Kuantitatif Kualitatif dan $R \& D$. Bandung: Alfabeta, cv.s.
Suryawati, Indah. (2014). Jurnalistik Suatu Pengantar Teori dan Praktik. Bogor : Ghalia Indonesia.

Sutojo, Siswanto. (2004). Membangun Citra Perusahaan : Building The Corporate Image. Jakarta: PT. Damar Mulia Pustaka.

Tamburaka, Apriadi. (2012). Agenda Setting Media Massa. Jakarta : PT. Rajagrafindo Persada.

Vos, M.F. (1992). The Corporate Image Concept: A Strategic Approach, Den Haag: CIP Gegevens Koninklijke Bibliotheek.

\section{Jurnal}

Cha, Heewon \& Yang, Sung-Un. (2011). Corporate Reputation and the news media in South Korea dalam Craig Carroll (Penyunting) Corporate Reputation and The News Media: Agenda Setting within Bussiness New Coverage in Developed, Emerging, and Frontier Markets. New York: Routledge.

Craig, Richard. (2005). Online Journalism (reporting, writing, editing for media). Canada: Wadsworth Belmont.

Dowling, Grahame. (2011). "Media analysis: what is it worth?. Journal of Business Strategy/Emerald Insight. Vol. 32 Iss 1 pp. 26 - 33.

Elsakit, Worthington. (2014). The Impact of Corporate Characteristics and Corporate Governance on Corporate Social and Environmental Disclosure: A Literature Review. Canadian Center of Science and Education, 9(1833-3850), hlm. 1-15.

Kuvykaite, Piligrimiene. (2013) Communication In Social Media For Company's Image Formation. Journal of Economic $s$ And Management Kaunas University of Technologies. 18(2), hlm 305-317.

Kurniawan, Hary (2016). Citra PT.PLN (Persero) Di Media Online.skripsi 
Departemen Ilmu Komunikasi Fakultas Pendidikan \& Ilmu Sosial. Bandung.

Mcnamara, Jim. (2005). Media content analysis: Its uses; benefits and best practice methodology. Asia Pacific Public Relations Journal, 6(1), 1- 34.

O’Leary, Daniel. (2015). “Using digital media to monitor and forecast a firm's public image" In Advances in Business and Management Forecasting. Emerald insight, 7, 207219.

Paulina, dkk. (2012). Citra Perusahaan Telekomunikasi DI Media Pasca Kasus Pencurian Pulsa. Studentjournal.petra.ac.id, 2(1), 111133.

Pijr, Anne Van. (2015). Crisis communication between corporation, the news media and public: the case of Primark. Amsterdam : Journal of Universiteit Van Amsterdam.

Renkema, Hoeken. (1998). ). The Influence of Negative Newspaper Publicity on Corporate Image in the Netherlands. The journal of business communication, 35, hlm.521-535.

Riel, Balmer. (1997). Corporate Identity: The Concept, Its Measurement and Management. European Journal of Marketing, 31(5/6), hlm.340-355.

\section{Artikel Ilmiah}

Michaelson, Griffin. (2005). New Model for Media Content Analysis. The Institute for Public Relations.

\section{Sumber Online}

www.Detik.com

www.pln.co.id 